\title{
UN MODELO PARA LA MUERTE: \\ LA APOTEOSIS DE PARODI
}

\author{
POR \\ ALFRED MAC ADAM \\ University of Virginia
}

Las colaboraciones literarias de Borges y Bioy Casares, los ensayos, las sátiras políticas o las ficciones detectivescas son parodias. Es en el nivel del lenguaje donde vemos la primera etapa de esta parodia: el lenguaje de Buenos Aires se transforma aquí en un espejo ${ }^{1}$ grotesco de la ciudad y de sus habitantes. Pero, al mismo tiempo que diferenciamos la parodia linguística de otros tipos de parodia, debemos observar que aunque la parodia es el rasgo esencial de estos textos, ellos se diferencian en términos de género. La parodia, entonces, es un aspecto de un texto, aspecto que no implica ningún valor taxonómico.

Sería oportuno comparar el término parodia con el término alegoría: la Faerie Queene, de Spenser, es una alegoría: la búsqueda de los varios héroes, los nombres que son definiciones de los demás personajes, hasta los nombres de los lugares mencionados en el poema, señalan al lector que lo que está leyendo es una alegoría. En cambio, Joseph Andrews, de Fielding, es una parodia: el lector del siglo xvin lo sabía porque la novela de Richardson Pamela era muy popular, y el protagonista de Fielding es el hermano de Pamela Andrews. Al mismo tiempo, la Faerie Queene es una epopeya renacentista y Joseph Andrews es una sátira novelesca. Es decir, el hecho de que la primera obra sea una alegoría y la segunda una parodia no hace más que orientar la lectura del texto; el género de la obra se determina por otros medios.

Los términos alegoría y parodia indican al lector que tendrá que mirar más allá del texto que lee si quiere entender lo que lee. La alegoría sugiere, por ejemplo, que hay varios niveles de lectura, que el texto puede tener un significado literal y también otras posibilidades. La paro-

\footnotetext{
1 Véase mi trabajo «El espejo y la mentira: dos cuentos de Borges y Bioy Casares», Revista Iberoamericana, núm. 75 (abril-junio 1971), pp. 357-374.
} 
dia, en cambio, es un sinónimo de intertextualidad. En ambos casos, el lector tiene que relacionar el texto con dos tradiciones: la de los lectores, que es una especie de know-how transmitido por medio de la educación, y la de la tradición literaria, que establece entre textos una red de alusiones, ecos y repeticiones que hace imposible la idea de un texto «original» creado en el aislamiento.

La parodia es un tipo especial de intertextualidad en que la repetición de un aspecto de un texto del pasado en un nuevo texto redefine aquel aspecto. La parodia establece una relación entre dos textos en que el texto nuevo, que no puede existir sin el texto antiguo, trata de subvertir o mejorar el significado y valor del texto más antiguo. Es decir, tenemos que ver la parodia en dos maneras muy diferentes: Fielding quiere ridiculizar el texto de Richard, la virginidad tenaz de Pamela, el triunfo de la moralidad burguesa, pero Flaubert quiere hacer algo muy distinto cuando incorpora en Madame Bovary elementos de las novelas sentimentales de su época: lo que Fielding muestra como ridículo, Flaubert lo eleva a un nivel estético más alto.

También hay que recordar que el fenómeno de la parodia no pertenece exclusivamente a la literatura. La parodia define una relación entre muchos modos de discurso, y lo vemos en la política y en los anuncios. Un ejemplo sería la famosa declaración de Lincoln Stephens cuando volvió de la Unión Soviética: "He visto el futuro, y este futuro funciona» («I have seen the future, and it works»), que una compañía internacional utiliza en su propaganda para anunciar sus avances en ciertas técnicas electrónicas. O el uso de la expresión «comprometerse», derivada del campo de la filosofía social, pero usada por compañías que producen cigarrillos para vender sus productos. La diferencia entre este tipo de parodia y la parodia literaria es que en la literatura una parte importante del proceso es el conocimiento que el autor asume al crear una parodia -que el lector tendrá en su memoria el texto parodiado-, mientras que en la propaganda el autor de la parodia depende de que su público sabrá o no que está citando (fuera de contexto, naturalmente) a alguien, o que la referencia será ambigua, una expresión retóricamente eficaz (como la frase de Stephens) desconectada de su contexto original.

En la literatura, el caso de Borges puede reflejar el tipo de parodia que vemos en los anuncios: ¿cómo debemos reaccionar cuando encontramos que la declaración patética del bibliotecario de «La biblioteca de Babel» es repetida por el nazi condenado de «Deutsches Requiem»? ${ }^{2}$.

${ }^{2}$ Jorge Luis Borges, «La biblioteca de Babel»: «Si el honor y la sabiduría y la felicidad no son para mí, que sean para otros. Que el cielo exista, aunque mi 
La frase «suena bien»; su significado cambia con el contexto. La parodia, a veces por medio de la repetición, invierte significados y engendra así ironía: la misma frase puede significar dos cosas totalmente antitéticas. En su forma más radical, la ironía es una mise en abîme en que los dos significados se cancelan mutuamente. (La ironía de Shakespeare en Measure for Measure es un ejemplo de esta ironía vertiginosa.)

Para ver la diferencia entre la parodia por medio de la caricatura y la parodia por medio de la repetición debemos comparar lo que hace Cervantes en el Quijote con lo que hacen Borges y Bioy Casares en su novela detectivesca Un modelo para la muerte ${ }^{3}$. En el Quijote, Cervantes parodia, entre otras cosas, la novela de caballerías: pero esta parodia está incorporada en una obra que no es una novela de caballerías. En Un modelo para la muerte, Borges y Bioy parodian las ficciones detectivescas, pero su texto sí es una ficción detectivesca. Parodiar un género dentro de los límites de ese género, como lo que hace con la comedia Shakespeare en Measure for Measure, que es o una tragedia cómica o una comedia trágica, produce paradojas: ¿está atacando el autor al género o está simplemente poniendo el género a prueba? ¿Ataca sólo el autor a ciertos recursos del género o hay un ataque más básico y radical en la parodia, un ataque contra la escritura misma como una copia o una representación falsa?

Un modelo para la muerte, como sugiere su título, es una ficción detectivesca en que un personaje mata a otro usando un cuento detectivesco de G. K. Chesterton, «El oráculo del perro», como modelo ${ }^{4}$. Y es en la idea del modelo, con sus ideas asociadas de copias, parodias y orígenes, donde podemos buscar acceso a este texto infernal. Chesterton es el modelo usado también para otras ficciones detectivescas por Borges y Bioy: los Seis problemas para don Isidro Parodi ${ }^{5}$ muestran muchas afinidades con los cuentos en que Father Brown es el detective, y hay muchas semejanzas entre Father Brown y el detective de Borges y Bioy, Isidro Parodi, el ex barbero encarcelado en la celda 273 de la penitenciaría, que resuelve misterios sin salir de la prisión.

lugar sea el infierno» (Ficciones, Buenos Aires: Sur, 1944, pp. 104-105); «Deutsches Requiem»: "Si la victoria y la injusticia y la felicidad no son para Alemania, que sean para otras naciones. Que el cielo exista, aunque nuestro lugar sea el infierno» (El Aleph, Buenos Aires: Emecé, 1962, p. 103).

${ }_{3}^{3}$ B. Suárez Lynch (seud. de Jorge Luis Borges y Adolfo Bioy Casares), Un modelo para la muerte (1946) (Buenos Aires: Edicom, 1970).

${ }^{4} \mathrm{G}$. K. Chesterton, «The Oracle of the Dog», The Incredulity of Father Brown, en The Father Brown Omnibus (New York: Dodd, Mead, 1951).

${ }_{5}^{5}$ H. Bustos Domecq (seud. de Jorge Luis Borges y Adolfo Bioy Casares), Seis problemas para don Isidro Parodi (Buenos Aires: Sur, 1942). 
El problema literario de modelos y orígenes se concentra en la figura de don Isidro: él mismo es la creación de Honorio Bustos Domecq, a su vez la creación de Borges y Bioy. Y como si esta cadena de creaciones no fuera bastante, el autor de Un modelo para la muerte es Suárez Lynch, discípulo de Bustos Domecq. Este hijo del monstruo de Frankenstein, este sobrino de M. Teste, escribe como su padre literario (Bustos Domecq), que no escribe de ninguna manera como sus padres literarios Borges y Bioy (aunque es posible ver la influencia de Bustos en ellos, en textos como «El aleph» o en $E l$ sueño de los héroes).

Esta caída en la jerarquía platónica - desde autores reales que crean representaciones hasta representaciones de autores que crean representaciones - produce un texto de carácter desarticulado, metonímico, «cuyo rastreo nada tiene de fácil», como confiesa Carlos Mastronardi ${ }^{6}$ en su reseña de la primera edición. Es difícil leer Un modelo para la muerte, no sólo porque recrea en un nivel hiperbólico el español porteño, desde el lunfardo hasta el estilo académico más puro, sino porque Suárez Lynch es un narrador tan lánguido que no nos enteramos hasta casi el final del primer capítulo que hay un crimen. En efecto, el texto está tan fascinado con su propia proliferación verbal que subordina la trama - el elemento más importante del género- al lenguaje. Si el misterio no fuera elucidado por un deus ex machina en la forma de una carta del criminal, el lector nunca podría descifrarlo.

Para interpretar el texto hay que resumirlo (otra parodia), no en la forma en que está narrado, sino en el orden cronológico de los hechos. En el pasado pretextual, el criminal, Ladislao Barreiro, sufrió a causa de las acciones de Tonio Le Fanu (cuyo parentesco con el novelista gótico irlandés no existe). Le Fanu hace que Barreiro pierda su puesto como director de una biblioteca. Barreiro promete vengarse. Mucho más tarde, Barreiro conoce a Kuno Fingermann, que resulta ser el cuñado de Le Fanu. Este hecho hace de Le Fanu un bígamo in potentia, pues está a punto de casarse con Hortensia Montenegro, de la «alta sociedad» porteña. Barreiro convence a Fingermann para que extorsione a Le Fanu. Al mismo tiempo, Le Fanu descubre que Fingermann ha robado dinero de la Asociación Aborigenista Argentina. Le Fanu le informa a Barreiro (abogado oficial del grupo) que extorsiona a Fingermann. Le Fanu se entera de todo y -improbablemente- extorsiona a Barreiro. El dinero pasa de Le Fanu a Fingermann, a Barreiro y vuelve a Le Fanu. Barreiro decide romper el círculo matando a Le Fanu, y lo hace así: convence

- Carlos Mastronardi, reseña de Un modelo para la muerte, Sur, núm. 146 (diciembre 1946), p. 96. 
a Le Fanu que sería mejor matar a Fingermann, y cuando Le Fanu ha preparado todo para sorprender a Fingermann, Barreiro lo mata.

El parentesco con el cuento de Chesterton «El oráculo del perro» no es del todo claro: en este cuento, un joven fracasado decide aprovecharse de las malas relaciones entre su primo y su tío. Sabe que su tío ha cambiado su testamento y cree que él recibirá su fortuna si el tío muere antes de poder cambiar otra vez el testamento. Escoge un momento en que el tío está en un pabellón hecho de varillas delgadas y lo mata con una espada muy delgada que logra meter entre las varillas. Nadie puede imaginar cómo el criminal logra matar al tío y escaparse sin ser visto por nadie, porque hay sólo una entrada al pabellón. El padre Brown, desde lejos, penetra el misterio porque nunca cede a la superstición y porque presta atención a los detalles. En esto es como Isidro Parodi, que tiene que borrar la identidad de cada personaje para aislar la información que necesita, la misma técnica empleada por el Dupin de Poe. En la carta en que Barreiro confiesa nos enteramos de que fue don Isidro quien le avisó que sería mejor que se fuera al Uruguay para evitar problemas con la policía.

La técnica de Un modelo para la muerte, volviendo ahora a pensar en la obra en su forma narrada, imita la de The Moonstone de Wilkie Collins: cada personaje presenta su versión de los hechos, y se enredan tanto que los hechos se pierden en la narrativa. La coherencia no es uno de los ideales de Suárez Lynch, y en su prólogo a la novela, Bustos Domecq le critica sus excesos. El prólogo es también el lugar en donde el texto se muestra como una parodia total: desde el principio, Bustos Domecq nos hace entender que Suárez Lynch es su discípulo, y en esto vemos la inversión de la inversión paródica tradicional. Aquí Bustos Domecq literalmente toma precedencia sobre Suárez Lynch - el precursor en un prólogo- al declarar que la idea "original» para la novela fue suya: la había encontrado entre los faits divers en el periódico. Añade Bustos Domecq que le regaló la idea al acólito porque estaba muy ocupado escribiendo algunos «bocetos biográficos», el mismo tipo de texto, curiosamente, que Suárez Lynch escribía antes de publicar Un modelo para la muerte. (Al escribir este prólogo para un principiante, Bustos Domecq estaría pensando también en su propio debut como escritor de cuentos detectivescos en Seis problemas para don Isidro Parodi; aquella colección contiene, además de un «boceto biográfico» de Bustos, un prólogo, no del todo favorable, por Gervasio Montenegro, que reaparece aquí como personaje.)

Bustos Domecq empieza el prólogo hablando de sí mismo, de su condición de ser un literato moribundo: «TTan luego a mí pedirme un 
'A manera de prólogo'! En balde hago valer mi condición de hombre de letras jubilado, de trasto viejo» (p. 7). En la próxima frase, este prologuista patético nos sorprende con un golpe bajo:

Con el primer mazazo amputo las ilusiones de mi amigo; el novato, quieras que no, reconoce que no hay tu tía, que mi pluma, icomo la de Cervantes, qué pucha!, cuelga de la espetera y que yo he pasado de la amena literatura al Granero de la República; del Almanaque del Mensajero al Almanaque del Ministerio de Agricultura; del verso en el papel al verso que el arado virgiliano firma en la pampa (p. 7).

En seguida, Bustos añade en un paréntesis orgulloso: «iQué manera de redondearla, muchachos! Todavía manda fuerza el viejito.» El significado de la expresión «Con el primer mazazo amputo las ilusiones de mi amigo» es ambiguo. No se usaría una maza para una amputación, pero lo que sí está claro es que en esta relación edípica, el padre moribundo sigue ganando batallas. Es decir, la inversión de la parodia queda invertida aquí, y el maestro logra castrar —metafóricamente- al acólito. Así se establece el tono de violencia aquí en el prólogo, y se anuncian los temas de venganza e imitación.

Aun así, no es hasta el capítulo 3 cuando sabemos algo concreto sobre los hechos que culminan en el crimen. Antes de aquel capítulo recibimos información inútil sobre la Asociación Aborigenista Argentina de Marcelo Frogman, factótum de ese anticlub para falsos indios, y datos superfluos sobre las relaciones amorosas de la élite porteña - si es que el círculo de Gervasio Montenegro (dueño de un prostíbulo y personaje también de Seis problemas para don Isidro Parodi) representa la élite porteña- Hacia el final del capítulo 3, el personaje que resulta ser el criminal, Ladislao Barreiro, menciona que ha leído el cuento de Chesterton «E1 oráculo del perro», cuento que Gervasio Montenegro, en el cuarto capítulo, llama «el más hermético de los textos anglosajones» (p. 75). Al final de la novela el cuento pasa de mano en mano y se transforma en una versión de la «carta robada» de Poe, un mensaje escondido donde todos lo pueden ver. Lo que da dignidad al cuento de Chesterton, su metafísica y su claridad religiosa, queda parodiado por Suárez Lynch; todo lo que deja intacto es la trama. Barreiro simplifica el cuento en esta forma:

Se mandaba el caso de un tipo con traje blanco que lo encuentran en estado fiambre en una glorieta. Vos te rompés el mate con la idea fija de cómo se las ingenió el criminal para espiantar del recinto, por- 
que había una sola arteria de acceso que la vigilaba un inglés de pelo colorado. Al final te convencen que sos un crosta, porque un cura descubre la matufia y te ponen la tapa (p. 66).

Este resumen contiene (junto con unos errores) un clue, inútil a menos que el lector haya leído el cuento de Chesterton y sepa todo lo que pasa en Un modelo para la muerte: el tío en Chesterton no muere en una glorieta, sino en un pabellón. Barreiro traduce el pabellón en glorieta porque él usa una glorieta (que una dama chilena utiliza para "prácticas venusianas») como la escena de su crimen. En esto y en asegurarse de que él no sería la persona más obviamente culpable, sigue el modelo de Chesterton.

El aspecto ingenioso de la novelita de Suárez Lynch, tomada como ficción detectivesca, es que, en las palabras de Barreiro, «las precauciones y las coartadas y las matufias corrieron a cargo de la víctima» (página 122). Es decir, Barreiro arregla las cosas de manera que la víctima, Tonio Le Fanu, esté en la glorieta para matar a Kuno Fingermann, y así el criminal se identifica con el autor como el que manipula los hechos para conseguir ciertos efectos. Naturalmente, aquí también hay una referencia al tema central, la parodia, noción implícita en toda ficción detectivesca: el criminal es el autor de la trama que incluye el crimen; el detective reescribe aquella trama para que termine con el criminal en la cárcel, y al mismo tiempo el autor lo domina todo, aunque está claro que usa tramas ya inventadas.

La trama de Un modelo para la muerte es casi invisible y cristaliza al final sólo porque hay una unidad de lugar en el cuento: todos los personajes recitan su versión de los hechos en la celda de don Isidro Parodi. El es la energía -en particular en este libro, donde apenas habla- que unifica el texto, y su celda es como una de las ventas en el Quijote, el lugar remoto a que viene, tarde o temprano, el mundo entero. Un modelo para la muerte es la apoteosis de Parodi porque es un texto donde la parodia se parodia a sí misma: aquí no hay ninguna frase que no sea absurda; aquí el detective se transforma en un cómplice del criminal. No lo sabemos hasta el último capítulo: la carta que manda Barreiro a don Isidro. Pero en realidad la carta viene de Borges y Bioy, porque el texto, al final, llega a una crisis en que la posibilidad de orden y significado está a punto de desaparecer.

El final de esta novela se parece al final de Measure for Measure, donde el mundo trastornado recupera su orden perdido, sólo que esta recuperación tiene lugar en el nivel de la letra y no en el del espíritu. La solución aquí corta el discurso, pero no resuelve nada. La falta de 
significado que amenaza a todo texto literario y la repetición loca de esta falta en la parodia son los verdaderos temas de Un modelo para la muerte. A pesar de los chistes, a pesar de un lenguaje esencialmente cómico, hay en esta narrativa un terror a punto de revelarse, el terror de un mundo donde el lenguaje pierde sentido. 